УДК 930.9

ББК 63.3(0)64

\title{
Ирано-туркменские отношения в XXI в.: эволюция и современное состояние
}

\author{
Ф.Б. Зокирзода, О.Ю. Курнькин
}

Алтайский государственный университет (Барнаул, Россия)

\section{Iranian-Turkmen Relations in the $21^{\text {st }}$ Century: Evolution and Contemporary State}

\author{
F.B. Zokirzoda, O.Yu. Kurnykin
}

Altai State University (Barnaul, Russia)

Ликвидация Советского Союза открыла для иранской внешней политики новое, представлявшееся весьма перспективным направление активности центральноазиатское. Иранское руководство рассчитывало укрепить международный статус страны за счет установления партнерских связей с государствами Центральной Азии (ЦА). На позиции первостепенного по значимости партнера для Ирана среди государств ЦА выдвинулся, вопреки ожиданиям, не близкий в этнокультурном отношении Таджикистан, а соседний Туркменистан. Основными сферами сотрудничества двух стран стали формирование трансграничной транспортной инфраструктуры в рамках создания международного транспортного коридора Север - Юг, а также энергетика, добыча и экспорт газа и нефти. Политика Ирана в Центральной Азии характеризовалась взвешенностью и прагматизмом. Тегеран не допускал резких шагов даже во время «газового конфликта» с Туркменистаном. Не меньшим прагматизмом отличалась и позиция Туркменистана, сохранившего широкий спектр взаимодействия с Ираном и вместе с тем сделавшего стратегический выбор в пользу сотрудничества с Китаем. Взаимодействие Ирана и Туркменистана оказывает стабилизирующее влияние на комплекс межгосударственных отношений в Центральноазиатском регионе.

Ключевые слова: Центральноазиатский регион, Иран, Туркменистан, трансграничные транспортные коммуникации, экспорт газа.

DOI 10.14258/izvasu(2019)2-10

Следствием распада СССР стало появление Центральноазиатского региона (в который входили ставшие суверенными Казахстан, Кыргызстан, Таджикистан, Туркменистан и Узбекистан) в ка-
The collapse of the Soviet Union opened a new, very promising direction of activity for Iranian foreign policy - Central Asia. The Iranian authorities hoped to strengthen the country's international status by establishing partnerships with the countries of Central Asia. Though Iran and Tajikistan shared similar ethnic and cultural traditions, surprisingly, neighboring Turkmenistan had become the most significant partner for Iran among the countries of Central Asia. The main areas of cooperation between the two countries were the formation of cross-border transport infrastructure in the framework of the creation of the international North - South transport corridor, as well as energy, gas and oil production and export. Iran's policy in Central Asia was characterized by balance and pragmatism. Tehran did not allow any drastic steps even during the "gas conflict" with Turkmenistan. Turkmenistan's position was no less pragmatic, as it retained a wide range of cooperation with Iran and at the same time made a strategic choice in favor of cooperation with China. Cooperation between Iran and Turkmenistan has a stabilizing effect on the complex of interstate relations in the Central Asian region.

Key words: Central Asian region, Iran, Turkmenistan, cross-border transport communications, gas export. честве регионального политико-территориального новообразования, занимающего важные стратегические позиции в центре Евразии. Оказавшись за пределами союзного государства, этот регион стал 
открытым для внешних влияний, он становится площадкой для реализации конкурирующих устремлений целого ряда внешних акторов. Среди последних по значимости и ресурсному потенциалу выделяются игроки первого ряда (Россия, США, Евросоюз, Китай) и игроки второго ряда, в основном региональные, а также внерегиональные державы (Турция, Пакистан, Индия, Саудовская Аравия, Япония и др.). Несомненно, к числу значимых, хотя не первостепенных акторов на центральноазиатском пространстве относится и Иран.

Центральноазиатский регион становится предметом анализа российских и зарубежных исследователей. Место региона в системе международных отношений анализировалось, например, в работе А.Д. Богатурова, О.Н. Тимофеева [1]. Политика мировых и региональных держав в Центральной Азии рассматривалась Л.В. Васильевым [2], А.В. Сулеймановым [3]. Особенностям политики Ирана в центральноазиатском регионе посвящены работы Д. Варнавского [4], М. Лаумулина [5], В. Месамеда [6], Э. Уостониджа [7] и др.

Ликвидация Советского Союза открыла для иранской внешней политики новое, представлявшееся весьма перспективным направление активности центральноазиатское. Исламская Республика Иран (ИРИ) с энтузиазмом отнеслась к появлению новых независимых государств Центральной Азии (ЦА) и одной из первых установила с ними дипломатические отношения. Иранское руководство рассчитывало укрепить международный статус страны за счет установления партнерских связей с обретшими независимость государствами Центральной Азии, расширения взаимовыгодных торгово-экономических связей с ними. В Тегеране надеялись также за счет активизации на центральноазиатском направлении ослабить международную изоляцию и последствия экономических санкций, введенных в целях сдерживания ядерных амбиций Исламской Республики. Принятый в 2005 г. Перспективный план развития Ирана, рассчитанный до 2025 г., ориентирует на превращение ИРИ в мощную региональную державу, претендующую на лидирующие позиции на Ближнем и Среднем Востоке и на весомую роль в сопредельных регионах [8]. В свою очередь для стран ЦА установление связей с таким самостоятельным игроком на мировой арене как Иран расширяло палитру внешнеполитической многовекторности и позволяло сбалансировать внешние влияния.

Иранская дипломатия, выстраивая отношения с центральноазиатскими государствами, располагала сильными козырями, но одновременно натолкнулась на серьезные ограничители в продвижении в этот регион. К факторам, благоприятствующим иранскому продвижению в Центральную Азию, относились географическое соседство, давние культурно-исторические связи, статус Ирана как крупного экспортера нефти, что порождало надежды на привлечение иранских инвестиций в экономику центральноазиатских стран. Однако вскоре выявились факторы, снижавшие привлекательность сотрудничества с Ираном для государств ЦА. Это затяжной конфликт ИРИ со странами Запада, побуждавший потенциальных партнеров Ирана к осторожности в сближении с ним, претензии ИРИ на роль оплота шиизма в мусульманском мире, теократическое облачение иранской государственно-политической системы, расходившееся со светскими основами государственности, закрепившимися в центральноазиатских республиках.

Иран выстроил различные модели взаимоотношений со странами Центральной Азии, определявшиеся степенью взаимной заинтересованности в установлении контактов, целями и возможностями в реализации внешнеполитических интересов и устремлений. Отношения Ирана с Узбекистаном и Казахстаном приобрели «умеренно дружеский» характер [2, с. 160], устойчивость, но не отличались масштабностью на фоне доминирования прозападного, пророссийского и прокитайского векторов во внешней политике этих двух лидеров региона. Отношения с Кыргызстаном, позиционировавшим себя как оплот демократии в регионе, остались весьма ограниченными. Наиболее перспективным партнером для Ирана среди центральноазиатских государств первоначально представлялся персоязычный Таджикистан, входящий в общее с Ираном и Афганистаном культурное пространство. Действительно, ИРИ сыграла ключевую роль в прекращении гражданской войны в Таджикистане в 1997 г., использовав свое влияние на исламские круги в рядах таджикской оппозиции. Однако в дальнейшем расчеты Тегерана на тесное сотрудничество с Таджикистаном не оправдались. Таджикское руководство, вытеснив исламскую оппозицию за пределы легального политического пространства, одновременно резко сузило формат межгосударственного таджикско-иранского взаимодействия. Таджикистан сделал стратегический выбор в пользу расширения сотрудничества с Россией, Китаем при поддержании на определенном уровне отношений с Западом. В результате на позиции первостепенного по значимости партнера для Ирана среди государств ЦА выдвинулся Туркменистан, а ирано-туркменские отношения продемонстрировали наибольшие стабильность и динамизм [6, с. 140]. В основе тесной кооперации двух стран - взаимная заинтересованность в сотрудничестве, меньшее влияние внешних противодействий на комплекс двусторонних отношений, отсутствие серьезных проблем во взаимоотношениях друг с другом.

Плотность и интенсивность контактов между Ираном и Туркменистаном обусловлены рядом 
факторов. Прежде всего наличием общей границы протяженностью около тысячи километров, что актуализировало вопрос о создании трансграничной транспортной инфраструктуры, способной не только обеспечить потребности в расширении грузооборота между двумя странами, но и стать важным звеном новой транспортной схемы всего Центральноазиатского региона, связывающей кратчайшим путем западные, восточные и южные районы Евразии. Соединение транспортных коммуникаций Туркменистана и Ирана открывало возможность для реализации масштабного проекта по созданию межгосударственного транспортного коридора Север - Юг как основополагающего элемента новой транспортной схемы внутриконтинентальной части Евразии. Однако реализация этого транспортного проекта сдерживается уязвимым международным статусом Ирана с неясными перспективами снятия санкций против него.

Тем не менее постепенно в Центральной Азии формируется новая транспортная система, правда, все больше разворачивающая в сторону Китая (в 1996 г. была введена в эксплуатацию транзитная железная дорога Теджен - Серахс - Мешхед, объединившая железнодорожную сеть Ирана и Туркменистана [9], в 2014 г. было завершено строительство железной дороги Узень - Берекет - Горган, связавшей Казахстан, Туркменистан и Иран [10], в январе 2018 г. начались контейнерные железнодорожные перевозки по маршруту Китай - Казахстан Туркменистан - Иран [11]). Таким образом, транспортная связка Туркменистан - Иран становится все более востребованной и работоспособной, обеспечивая перевозку миллионов тонн транзитных грузов и принося в бюджет этих стран дополнительно десятки миллионов долларов.

Высокой динамикой отличается ирано-туркменское сотрудничество в энергетической сфере. Иран является крупнейшим импортером туркменской нефти. Тегеран оказывает содействие Туркменистану в транзите нефти через иранскую территорию к портам Персидского залива. Еще большее значение имеет иранский маршрут для экспорта туркменского газа.

В Тегеране питали надежды на превращение иранского транспортного коридора в основной для экспорта туркменского газа на мировые рынки. Однако этим надеждам не суждено было сбыться, что было обусловлено прежде всего активизацией с середины первого десятилетия XXI в. на центральноазиатском пространстве Китая как игрока, способного оказать решающее влияние на переформатирование торгово-экономических связей и транспортных схем в регионе. Соглашение о сотрудничестве в нефтегазовой отрасли между Китайской национальной нефтегазовой корпорацией (CNPC) и Министерством нефтегазовой промышленности и минеральных ре- сурсов Туркменистана, подписанное в 2006 г., не только стало прорывным в двусторонних отношениях, но и заложило основу для формирования новой схемы трубопроводного транспорта в Центральной Азии, ориентированной на удовлетворение потребностей в энергоресурсах быстро растущей китайской экономики. Китайские инвестиции были направлены на освоение туркменских газовых месторождений, строительство газоперерабатывающих мощностей и газопроводов до китайской границы. Есть основания утверждать, что Китай стал главным бенефициаром в соперничестве за доступ к энергоресурсам Центральной Азии. К 2021 г. предполагается довести объем поставляемого в Китай туркменского газа до 65 млрд куб. м [12, с. 205]. Строительство и ввод в эксплуатацию четвертой линии газопровода в Китай сделает последний практически монополистом на туркменском газовом рынке. К тому же после временной приостановки в 2016 г. возобновлены с апреля 2019 г. поставки туркменского газа в Россию [13]. В сложившихся условиях возможности иранского участия в газовых проектах Туркменистана резко сокращаются. Ежегодный экспорт туркменского газа в Иран составляет от 8 до 16 млрд куб. м [12, с. 205], потребляется он внутри Ирана. Последний обладает собственными крупными запасами газа, что обусловливает лимитирование на закупки газа в Туркменистане. Таким образом, Китай, протянув три нитки газопроводов до своей границы, сделал нереалистичными расчеты на превращение Ирана в основного транзитера туркменского газа на мировой рынок.

Позиции Ирана на газовом рынке Туркменистана были ослаблены в результате возникшего в 2017 г. конфликта из-за прекращения поставок туркменского газа в Иран и судебных разбирательств между Иранской национальной газовой компанией и Туркменгазом. Конфликт возник из-за разногласий в отношении цены за туркменский газ (Ашхабад поднял цену за газ, намереваясь дополнительно получить с Ирана $\$ 1,8$ млрд, с чем была не согласна иранская сторона [14]).

Несколько ограниченный в наборе инструментов и средств продвижения в Центральную Азию, Иран акцентирует внимание на осуществлении культурной экспансии в регионе, реализуя свой вариант «мягкой силы». Иран активно пропагандирует положение о культурной общности с народами Центральной Азии. В частности, в отношении Туркменистана Иран апеллирует к общности исторических судеб двух стран (территория современного Туркменистана неоднократно входила в состав иранского государства). В 1999 г. в Ашхабаде был открыт иранский культурный центр, учрежденный Организацией по культуре и исламских связей (аналогом Британского совета и Института Конфуция) [7, c. 134]. 
Показательно, что наличие многочисленной туркменской общины в северо-восточных областях Ирана не стало серьезной проблемой в двусторонних отношениях (несмотря на потенциальную угрозу распространения ирредентистских настроений), и вопросы, связанные с положением туркменского меньшинства в Иране, решаются с учетом пожеланий обеих сторон.

Как показали дальнейшие события, первоначальные опасения по поводу экспорта Ираном в страны Центральной Азии исламской революции и собственной исламской модели государственности оказались преувеличенными. Политика ИРИ в отношении центральноазиатских государств в целом являлась сдержанной и прагматичной. Объективно Иран заинтересован в стабилизации ситуации в регионе и наращивании потенциала двустороннего сотрудничества. Эта сдержанность обусловлена не только трезвым учетом своих возможностей, но и желанием не обострять отношений с Россией, озабоченной обостряющейся конкуренцией за влияние на государства ЦА. Два десятилетия XXI в. подтверждают вывод об «обреченности» Ирана и Туркменистана на активные двусторонние связи [6, с. 141], впрочем, с учетом динамики ситуации и изменения баланса сил в Центральноазиатском регионе и вокруг него.

Очевидно, Ирану не удалось реализовать все свои амбициозные планы на центральноазиатском пространстве, приобрести прочные позиции в качестве стратегического партнера для государств региона. Тем не менее ИРИ представляется значимым фактором в общем балансе внешних влияний на страны региона. Политика Ирана в Центральной Азии характеризовалась взвешенностью и прагматизмом. Тегеран не допускал резких шагов даже при возникновении «газового конфликта» с Туркменистаном. Не меньшим прагматизмом отличалась и позиция Туркменистана, сохранившего широкий спектр взаимодействия с Ираном и вместе с тем сделавшего стратегический выбор в пользу сотрудничества с Китаем. Есть основания полагать, что взаимодействие Ирана и Туркменистана оказывает стабилизирующее влияние на комплекс межгосударственных отношений в Центральноазиатском регионе.

\section{Библиографический список}

1. Международные отношения в Центральной Азии. События и документы / отв. ред. А.Д. Богатуров. М., 2011.

2. Васильев Л.Е. Некоторые особенности политики мировых держав в Центральной Азии // Китай в мировой и региональной политике. История и современность. 2012. № 17.

3. Сулейманов А.В. Геополитическая борьба России, Турции и Ирана в Центральной Азии и Закавказье // Вестник Российского университета дружбы народов. Серия: Международные отношения. 2013. № 4.

4. Варнавский Д. Иран и государства Центральной Азии: генезис, состояние и перспективы сотрудничества // Центральная Азия и Кавказ. 2008. № 2(56).

5. Лаумулин М. Центральная Азия и Рах Iranica: взаимодействие и взаимовлияние // Центральная Азия и Кавказ. 2011. № 2 .

6. Месамед В. Ирано-туркменские отношения в эпоху перемен // Центральная Азия и Кавказ. 2007. № 4(52).

7. Уостнидж Э. Внешняя культурная политика Ирана в Центральной Азии: демонстрация политического прагматизма // Центральная Азия и Кавказ. 2014. Т. 17, вып. 4.

8. Вартанян А.М. Стратегия развития Ирана до 2025 года: промежуточные итоги [Электронный ресурс]. URL: http://www.iimes.ru/?p=11270.
9. Транзитная железная дорога Теджен - Серахс Мешхед стала важным источником валютных доходов для Туркменистана [Электронный ресурc]. URL: https:// www.iran.ru/news/economics/39888/Tranzitnaya_ zheleznaya

10. Тестовый контейнерный поезд из Китая проследовал через Туркменистан в Иран [Электронный ресурс]. URL: https://turkmenportal.com/blog/13072/testovyi-konteinernyipoezd-iz-kitaya-prosledoval-cherez-turkmenistan-v-iran.

11. Геополитика железных дорог: Иран и Китай в Центральной Азии [Электронный ресурc]. URL: https:// nk.org.ua/geopolitika/geopolitika-jeleznyih-dorog-iran-ikitay-v-tsentralnoy-aziii-87128.

12. Парамонов В., Строков А. Китайское присутствие в нефтегазовом секторе Туркменистана // Центральная Азия и Кавказ. 2015. Т. 18, вып. 3-4.

13. «Туркменгаз» сообщил о возобновлении поставок топлива в Россию [Электронный ресурc]. URL: https:// fergana.agency/news $/ 106649 /$ ? country=tm.

14. Иран намерен судиться с Туркменистаном за прекращение поставок газа [Электронный ресурс]. URL: https:// neftegaz.ru/news/partnership/213291-iran-nameren-suditsyas-turkmenistanom-za-prekrashchenie-postavok-gaza/ 